\title{
МИКРОБИОЛОГИЧЕСКИЕ МАРКЕРЫ ПРИ РАЗНЫХ ФЕНОТИПАХ ОЖИРЕНИЯ (ПИЛОТНОЕ ИССЛЕДОВАНИЕ)
}

\author{
Ганенко Л.А., Волкова Н.И., Набока Ю.Л., Оксенюк О.С.
}

ФГБОУ ВО «Ростовский государственный медицинский университет» Минздрава России, Ростов-на-Дону.

ЦЕЛЬ: изучить композиционный состав микробиоты толстой кишки у пациентов с разными фенотипами ожирения.

МАТЕРИАЛЫ И МЕТОДЫ: для реализации поставленной цели были обследованы 37 пациентов. Всем обследуемым выполняли количественную оценку состояния микробиоты толстой кишки методом Realtime PCR и определяли биохимические показатели крови. После чего, на основании критериев Wildman были сформированы 3 группы: 1 группа $(n=11)$ - здоровые люди без ожирения и избыточного веса, 2 группа ( $\mathrm{n=13)}$ - больные с метаболически здоровым ожирением (M30), 3 группа $(\mathrm{n}=13)-$ пациенты с метаболически нездоровым ожирением (МН3О).

РЕЗУЛЬТАТЫ: в 1 группе (здоровые люди) в микробиоте толстой кишки по сравнению с формально-нормативными показателями снижено $(p<0,05)$ количество Lactobacillus spp., Bifidobacterium spp., B. thetaiotaomicron и повышены $(p<0,05)$ показатели общей бактериальной массы и Enterobacter spp. / Citrobacter spp. У обследуемых 2 группы (М3О) наблюдались изменения микробиоты аналогичные 1 группе. Однако в отличие от 1 группы в фекалиях регистрировались Klebsiella spp. и Proteus spp. в количествах превышающих формально-нормативные. У обследуемых 3 группы (МН3О) помимо изменений, выявленных в 1 и 2 группах в фекалиях обнаружены C. difficile, а также значимое $(p<0,05)$ снижение F. prausnitzii и повышение $(p<0,05)$ частоты обнаружения банальных E. coli.

Выводы: полученные в результате нашего пилотного исследования данные, свидетельствуют об отчетливых изменениях микробиоты толстой кишки у людей с разными фенотипами ожирения, которые потенциально могут быть либо причиной и/или отображать разные фенотипы ожирения. Запланировано дальнейшее изучение микробиоценоза толстой кишки у пациентов с различными типами ожирения, но уже с большим количеством обследуемых в группах для получения подтверждения выявленным изменениям в пилотном исследовании.

КЛЮЧЕВЫЕ СЛОВА: ожирение; метаболически здоровое ожирение; микробиота толстой кишки. 